\title{
CONTRACT LAW IN A COMPARATIVE PERSPECTIVE
}

\author{
Suharnoko $^{1}$
}

\begin{abstract}
The development of Indonesian contract law has been influenced by enacment of new law, court verdicts and legal practices. It has been influenced by civil law and common law systems applied in other countries as well. The enacment of Consumer Protection Act strenghtens position of consumers against profesional seller. The Basic Agrarian Law and its Implementation Laws improve certainty in ownership of land. Courts have recognized, the doctrine of undue influence, acceptance by conduct, but they have not recognized pre contractual liability and have not applied the doctrine of unjustified enrichment in disputes regarding illegal contract. As practical matter, the integration clause under common law system stipulated in contract governed by Indonesian law, whereas Internasional Convention on Sale of Good regarding this issue adopts civil law system.
\end{abstract}

Keywords: contract law, civil law, common law, consumer law, agrarian law.

\section{Introduction}

Contract in Indonesia are governed by either adat (customary law) or the Civil Code. Generally adat law governs contracts between people of the indigenous population in a village setting. Adat law was not applied for the European or international transaction. For the European and foreign eastern their transaction govern by the law of obligation stipulated in the Book III of Civil Code. When member of these different groups of people concludes contract with one another, a choice of law problem comes up and it can be resolved by one of the following principles.

a) Intention of the parties. The parties made an explicit statement in the contract that either adat law or the Civil Code applies in resolving of that legal issue. The court may also make assumption that contracting parties impliedly has made choice of law. For example when the court find that, certain legal terms and concept are recognized in one of two legal system the law of that system would apply. Form and substance of the contract could also be a factor. For example, if the said contract is never dealt with one of the system therefore it is clear that the law of other system shall be applied. That a corporation, whether owned by native or Chinese or European fall under the Civil Code. This follow from the fact that corporations are basically western legal entities.

${ }^{1}$ Suharnoko is a lecturer of international Law, Faculty of Law, University of Indonesia. Obtained Bachelor of Law (S.H.) from University of Indonesia (1983), Master of Arts in Legal Institution (MLI) from University of Wisconsin (1996). 
b) Milieu. If the transaction takes place in a village milieu, then adat law shall be applied. For example, if European own a store in a small village and lease it to a villager, then adat law shall be applied. On the other hand, if a villager owns a home in Jakarta and lease it to European, then the Code shall be applied since it is generally used in Jakarta.

c) Entrance into the law sphere of the other party. If one goes to another domicile to make transaction then the said transaction must be governed by the law where the transaction takes place. For example, if the natives Indonesian goes to European or Chinese owned store to buy something he has enter to sphere of western law then the Civil Code shall be applied. But if a foreign salesman goes to the village to sell his merchandise he has entered the sphere of native law and then the adat law shall be applied.

d) Public Offer. If one make offer to public and another accept his offer then sphere of his sphere be applied to such transaction.

e) Overpowering economic and social position of one party. The law assumes that one overwhelming party can dictate its one term. Therefore, it is logical to apply the law from the sphere of this party. For example, native Indonesia living in village, buy an airline ticket, as a legal consequence, the Civil Code shall be applied. ${ }^{2}$

\section{Before the Contract: Negotiation in Good Faith, Breaking off and Remedies}

As a general rule a contract is concluded at that meeting of mind. This is the so called consensual principles which forms the basis of contract embodied in article 1320 point one the Civil Code. This principle is also found in article 1458 the Civil Code that a sale contract is valid and binding to the contracting parties at the moment the contracting party has consent on good and price. However for the validity of certain contract it requires formality. For example, to be valid a compromise contract shall be reduced in writing. Another requirement is found in deposit contract that for the valid contract the said good shall be delivered by a bailor and be accepted to the physical possession of the bailee.

What ever the contract is, it can be said that mutual consent is the basic principle for valid contract. There are four basic requirements that must be fulfilled be fore a contract is legally binding: the contract must be concluded based on free will of the parties. The party making agreement must be legally has capacity to do so; the contract must be supported by a certain definite matter agreed upon and the subject mater of the contract must be legal. According to article 1338 paragraph one of the Civil Code, once an agreement is satisfied requirements for valid contract stipulated in article 1320 the Civil Code it becomes legally binding to the contracting parties. Furthermore article 1338 paragraph 3 the Civil Code provided that the said contract shall be performed with good faith. To ensure good faith a judge in civil case has discretionary power to supervise the implementation of the contract, and to invoke principles of reasonableness and justice in doing so. As a practical matter, this means that a judge is free to deviate from the letter of the contract if such deviation is

${ }^{2}$ Charles Himawan and Mochtar Kusumaatmadja, (1973). Business Law: Contract and Business Association. Bandung: Fakultas Hukum Universitas Padjadjaran. p.1-2. 
necessary to ensure good faith. For example, in famous case, the Supreme Court held in case dated May, 11, 1955 that a piece land which had been pledged for Rp.50 prior to World War Shall NOT be redeemed for the same price. According to the Supreme Court since the price of gold had increased 30 times during the intervening years therefore the risk of currency fluctuation be born equally by the parties even though the contract fixed price of redemption at Rp.50,- The Supreme Court held and ordered the plaintiff to pay $1 / 2$ of 30 X Rp.50,- it I equal to Rp.750,- for the land. Although the particular case involved adat law, it is good example that the court was willing to invoke the principle of good faith as to intervene and modify contract provisions where such intervention is necessary to satisfy the standards of reasonableness and justice. ${ }^{3}$

Another principle of good faith, it is related to the protection of bonafide purchaser. For example in the case of a debtor fraudulently convey its property to third party in order to conceal its assets, the Civil Code provides a special course of auction, namely Actio Pauliana stipulated in article 1341 the Civil Code. The creditor can avoid the consequence of those transactions made by the debtor an other by obtaining a court order revoking it. To be revocable, the transaction in question must be extraneous to those required by the contract and it cause detriment to creditor. Ordinarily, the damages exist whenever the debtor reduces his property to a point where it is not sufficient to cover all his debts. However, the right of a bonafide purchaser, are independently protected and shall not be effected by such revocation.

Article 1340 the Civil Code provides that agreement shall be valid exclusively between contracting party, and the said agreement shall not be detriment to third party.

Article 1341 the civil code states that However, every creditor may call for cancelation of all non obligated action by the debtor, which are detrimental to creditor provided that the creditor must prove its debtor and person to whom he make transaction were knowledgeable that detriment to the creditor would be the result.

Whether the performance of contract constitutes good faith is belongs to question of law.

The current legal issue is whether the principle of good faith shall be exist at performance of contract only or shall be exist at that time when a contract is concluded or even it shall be exist during the course of preliminary negotiation before contract as well?

For comparison, in the Netherlands, the Supreme Court had recognized that the principle of good faith shall be exist before a contract is concluded. It was held in Hoge Raad Verdict dated 18 June 1982, NJ 1983,723.. In the late 1974 Plass proposed an offer to perform contract of work in the City of Valbrug. During the meeting, the Major of Vilbrug told and ensured that Plass proposal had been accepted but formally it should be decided by the Board of City meeting. However, in fact the Board of City decided in its meeting that another contract of work proposal made by Arns BV win the said tender and was accepted by the Board of City. Therefore Plass brought this case to the court and claim for damages. The District Court and the Court of Appeal held in favor of Plaas and awarded actual damages to compensate the expense paid by Plass. The reason is that the principle of good faith shall exist before contract is concluded. Since

\footnotetext{
${ }^{3}$ R.Subekti, (2004). Hukum Perjanjian. Jakarta:Intermasa. p. 41-43.
} 
there was no contractual relationship between the City of Valbrug and Plass, the court awarded actual loss only instead of expectation damages. However Hoge Raad held that when the preliminary negotiation almost reach final consensus, the aggrieved party may ask for expectation damages to compensate his expectation loss. ${ }^{4}$

Critique to the Hoge Raad verdict that form the perspective of classical legal doctrine, the purpose of breach of contract claim is to put he plaintiff to the position if he would have been in had the contract been performed and therefore the plaintiff is deserve for expectation damages or winstderving (Dutch). On the other hand the purpose of tort claim is to put the plaintiff to the position before such tort occurred and therefore the plaintiff deserves only for actual damage to compensate its reliance loss.

Similarly, in French when during preliminary negotiation, one just rescinds from negotiation without good causes he shall be liable for tort. Moreover when the said negotiation almost reach a final agreement, one who rescinds from negotiation shall be liable for breach of contract. In Germany since 1960's court have developed a rule that one who rescinds from negotiation without good cause and it causes another's investment becomes not worthy shall be liable for such damage. ${ }^{5}$

For comparison, in the common law country like USA, the court applied the doctrine of promissory estoppels to protect one who rely on another promise during preliminary negotiation. Originally the doctrine of promissory estoppels in England, is a response to the doctrine of consideration. Under the doctrine o consideration, promise is not legally binding without consideration. Consideration is something be given in return, it gives benefits to promisor and detriment to promisee. However under the doctrine of promissory estopel, a promise is legally binding without consideration provided that: promisee rely on promise; such reliance makes him do something or forbearance; when promisor rescinds his promise it cause damage to promisee. For example in London Property T Ltd v Hight Tress House Ltd (1947), K.B.130, the Plaintiff leased a block of flats in London to the defendant for 99 years for price 2,500 pound sterling per year. In the period o war it was difficult to find people who want to live at this apartment and therefore the plaintiff agreed to decrease the rent price for 1,250 pound sterling. After the war as over the plaintiff sue the defendant to fully pay the rent price for the whole period. The court held the promise to decrease the rent price was valid and binding even though without consideration. ${ }^{6}$

In well known case Hoffman v Red Owl, (1965) Red Owls Stores during preliminary negotiation deliver a promise to give a franchise contract for Hoffman with a conditional precedent. Hoffman was required to invest amount of 18000 US Dollar. In reliance to Red Owl Stores promise, Hoffman bought a premise for his prospective store and leased a house for his family in Chilton. However Red Owl Stores breach its promises and asked for more investment. Hoffman can not afford it and Franchise Contract was not concluded between them. Under the classical legal doctrine, there is no liability during preliminary

\footnotetext{
${ }^{4}$ Van der Burgh. (1999). Buku tentang Perikatan dalam Teori dan Yurisprudensi. Trj.F.tengker, Bandung: Mandar Maju. p. 95-96.

${ }^{5}$ Jack Beatson and Daniel Friedman(ed). (1999). Good Faith and Faults in Contract Law. Oxford: Clarendon Press., p 38.

${ }^{6}$ A.G. Gust.(ed). (1975). Anson's Law of contract. London:Clarendon Press. p.113.
} 
negotiation and therefore Red Owl Stores was not liable for such expenses paid by Hoffman. In this case the franchise contract had not been exist yet. Red Owl and Hoffman have not reach agreement in term of fees, royalty and duration of contract. The classical legal doctrine clearly make border line between pre contractual relationship without liability and contract relationship with liability. However the Wisconsin Supreme Court adopted a modern legal doctrine that put sense of justice superior to certainty. Therefore, the Wisconsin Supreme Court held that Hoffman deserve for compensation and awarded him reliance damages for his reliance loss. The most interesting part of this case is that the court was only awarding reliance damages for the expenses and not awarding expectation damages since the franchise contract has not been concluded yet. ${ }^{7}$

For the perspective of Indonesian law, it is necessary to analyze whether in implementing laws and regulations, courts apply the doctrine of good faith during preliminary negotiation. As it is mentioned in article 1338 paragraph 1 that, once an agreement satisfies requirements for valid contract it become legally binding to contracting parties. Therefore according to article 1338 paragraph 2 contract can not be revoked unilaterally except there is reasonable reason stipulated by law to revoke it unilaterally. Furthermore article 1338 paragraph 3 mentions that contract shall be performed with good faith. The principle of good faith gives discretionary power to judges to deviate from literal meaning of contract if the application of literal meaning will cause injustice to contracting parties. For example in Ny Boesono and R Boesono v. Sri Setianingsih, case No. 3431/K/ Pdt/1985 dated 4 March 1987, the Supreme Court held that even contracting parties consent for $10 \%$ interest rate monthly, it constitute injustice. Boesono family is retired person who desperately need money. Boesono pledged its pension book to secure the said loan. According to the Supreme Court $10 \%$ interest rate was to high and therefore the Supreme court cut it to $1 \%$ monthly. The interesting question of this case that whether the principle of good faith shall be exist in performing contract or it shall be exist in concluding contract.

According to classical legal doctrine, the principle of god faith can be applied only when the contract satisfies the requirement of certainty/certain subject matter. Following this classical legal doctrine, the principle of god faith can not be applied in the stage of preliminary negotiation. For example in N.V. Aniem v. Said Wachidin case No.235/1953 Pdt, dated 13 August 1958 the Appeal Court of Surabaya held that NV. Aniem the provider of electric had no obligation to supply electric for movie theater belonged to Said Wachidin. The agreement between NV Aniem and Said Wachidin was silent to the term of quantity and therefore was no contract. In this case Said Wachidin had paid the cost for electricity equipment. Moreover, Said Wachidin claimed for expectation damages for Rp 297.822,-. It was calculated from 21 February 1952, date when NV Aniem should have supplied electric to his theatre until 16 May when he him self provided electric for his theatre. The Supreme Court held in favor of NV Aniem since according to the Supreme Court, there was no contract and therefore there was no obligation to supply electric. Critique to this verdict that article 1333 the Civil Code states that the quantity may be unspecified but afterward it can be determined in performance of contract. It means that even the agreement has no quantity, it still valid as long as it can be determined in performance of

${ }^{7}$ Donald Harris and Denis Tallon (ed). (1989). Contract Law Today:Anglo-French Comparison. Oxford: Clarendon Press. p.27. 
contract. Moreover the quantity can be determined by way of interpretation. Article 1339 the Civil Code mentions that agreement shall be binding as to what it is stated specifically by the terms, but also with regard to all the nature of such agreement, or in terms of fairness, customs or law. Furthermore article 1347 the civil code states that all customary conditions shall be deemed impliedly be a part of agreement, although it is not specifically mentioned in the agreement.

In another case involving housing consumer who read an advertisement in brochures stating that the real state company provided fishing and recreation facility in housing location. Relying on promise stipulated in brochures, they bought houses through credit facilities from Bank Tabungan Negara, but in fact there were no such facilities build by the real state company. They claim for damages but the Supreme Court in case No. 3138 K/Pdt/1984 dated 29 April 1997 denied it. According to the Supreme Court, the site plan did not show that there was planning to develop fishing and recreation facilities. This site plan was already verified by the local government and therefore there was no obligation for the housing estate to build such facilities. The Supreme Court verdict represented classical legal doctrine point of view that information provided in brochures did not created obligation and there was no pre contractual obligation.

Under the Law Number 9 Year 1999 on Consumer Protection, article 9, the entrepreneur is not allowed to make false advertisement, mislead consumers.

Another legal issue regarding negotiation and contract is when negotiation becomes a legally binding contract. Business people some times make Memorandum of Understanding before entering a legally binding contract. Memorandum of Understanding is a written statement detailing preliminary understanding of parties who plan to enter into contract or some other agreement. It is non committal writing preliminary to a contract. Memorandum of Understanding is not meant to be binding and does not hinder the parties from bargaining with third party. But courts occasionally find that a commitment to enter contract has been made. For example two parties voluntary perform the said MOU. If only one party perform MOU it could be create pre contractual liability based on the duty to negotiate with good faith or promissory estoppels.

The negotiating parties may be does not reach a final agreement and break off the negotiation. The legal issue is whether the parties is bound by oral agreement on basic term such as good and price. It is important issues under Indonesian law that article 1458 the Civil Code states that sale contract is valid and binding at the time when parties have agreed on the good and the price, even if the good has not been delivered and the price has not been paid. The sale contract constitutes consensual and obligator principle. By consensual means the sale contract is valid upon consent on good and price but it is only creates obligation between contracting parties. The seller has obligation to deliver the good and the buyer has obligation to pay the price. It means that sale contract does not constitute transfer of title from seller to buyer. Transfer of title shall be performed in accordance to article 1459 the Civil Code. Therefore it is suggested that during preliminary negotiation the parties may state that "the parties do not intent to be bound except by a written agreement signed by both parties containing mutually acceptable terms of transaction".

However under the Civil Code, contract may conclude in written document or in oral agreement. Sometimes the intent of parties to make legally binding 
contract can be interpreted by facts and circumstance evidence related to their transaction. Moreover, the offeror may determine how offeree make acceptance. But remember there is a doctrine that "silence can not be acceptance". Acceptance can be made by conduct. For example read this clause "you should carefully read the following terms and condition before opening the diskette package. Opening the diskette package indicate your acceptance of these terms and condition. If you do not agree with them, you should promptly return the package unopened and your money will be return". This kind of clause found in license software computer program namely "Shrink-Wrap".

After one deliver offer, another may confirm it that he agrees with the term and condition but with some modifications in separate document. The legal issues is whether such modification constitutes acceptance an therefore become a part of legally binding contract. It be more crucial when such modification is "material", such as, price, quantity or payment. For comparison under common law case there is legal doctrine that counter offer is not offer. In Hyde v Wrench case, Wrench offer to sell price 1000 pound sterling and Hyde ask for 950 pound sterling but Wrench refuse it. Finally Hyde agree for 1000 pounds sterling but Wrench say no. The legal issue is whether a contract is concluded or not? Under the doctrine namely "mirror image rule" that acceptance must be correspond exactly with the term of offer. Therefore there was no contract since when Hyde ask for 950 pounds sterling it constitute counter offer or new offer. However for comparison, the Uniform Commercial code allows modification unless offeror expressly states that acceptance must be materially correspond to offer or offeror has denied modification in reasonable time.

In conclusion a negotiator of offeree may propose a modification to add or to alter the contains of contract and it becomes a part of contract. On the other hand a negotiator of offeror may prevent such modification becomes apart of contract by making statements as follows:

(1) Acceptance subject to the condition in the reserve side;

(2) Offeror expressly limit acceptance to the terms of this offer. Offeror object to the inclusion any different or additional terms proposed by offeree, and if they are included in offeree acceptance, a contract for sale will result upon offeror's term stated herein.

(3) Acceptance of this offer must be made on its exact term and if additional terms or different terms are proposed by offeree its respond constitute counter offer and no contract shall come into existence without offeror's assent to the counter offer.

The first option only states that clauses stipulated at reserve side is a part of offer. The third option states that modification or addition clauses from offeree is not binding contract without offeror's assent. Therefore if both parties perform contract, it means that the offeror agree with modification made by offeree. ${ }^{8}$ For example, in PT Dua Berlian v. Lee Kum Kee, case Number 1284K/ Pdt/1998 dated 18 December 2000, the Supreme Court held that even under the written distributorship agreement said that the agreement was valid for one

${ }^{8}$ Scott J. Burnham. (1993). Drafting Contract. Charlottesvile,Virginia: The Michie company. p.21- 
year only, but the facts that Lee Kum Kee continue supplied sauces and PT Dua Berlian made paymen after one year it was created a silent agreement. When Lee Kum Kee, unilaterally terminate the contract it constituted tort that immediate termination was unproper counduct violated the duty of care. In conclusion the second statement is the best option fo offeror to prevent modification proposed by the offeree.

Finally it is important to know when offer and acceptance creates a contract. When offeror and offeree makes instant communication it is easy to determine when the contract is created. But when they involves in non instantaneous communication, there two legal theory applied. Firstly, mail box theory. Under mail box theory a contract is concluded when an offeree send its acceptance to an offeror regardless it is received or not by an offeror. Another legal theory namely received theory that a contract is created when offeror received an acceptance mail sent by offeree. Countries with civil law system usually apllies received theory. For example the Law Number 11 Year 2008 on Information and Electronic Transaction, article 20 says that electronic transaction is concluded when acceptance is received by offeror, unless contracting parties stipulates otherwise. Whereas, most common law countries apply mail box theory. However there is an opinion that electronic transactions shall be divided into instant communication and non instantaneous communication. Transaction by electronic mail is non instantaneous and therefore the mail box theory is applied, whereas transaction by web site is instant communication and therefore the received theory is applied.

\section{Formation of Contract: Void and Voidable Contract}

To establish a valid contract, four elements are required under article 1320 the Civil Code. They are mutual consent of the parties; legal capacity to contract; a certain subject matter and legal cause. Mutual consent and legal capacity are called subjective requirement that those are related to contracting parties whereas a certain subject matter and legal cause are classified as objective requirements that they related to contains of contract. When subjective requirements are not satisfied it causes a contract become voidable. Voidable means that a contract is still valid before judges make annulment and as long as the ground for annulment is not invoked by contracting parties, the contract is still valid. Whereas null and void means that an agreement among parties does not cause legal relationship between them. There is no obligation to perform the said agreement and there is no legal cause to claim any rights before the court. Judges, ex officio shall declare a contract void, even thought contracting parties do not invoke the ground for nullity. ${ }^{9}$

Consensus basically is mutual consent between parties and such mutual consent must be declared in written document or orally. Consent must be given based on free will without mistakes, duress or fraud. Mistake has to be in relation to the substance the quality or the subject matter of contract. For example a person wants to buy a ring of gold but it turns out that he has bought a ring of copper. It is necessary that the other party knows that his counterpart is in error and nevertheless does not warn him.

By duress means a psychological pressure or intimidation. The person intimidated must be afraid that something will harm him personally or his family

${ }^{9}$ R.Subekti. Op.Cit. p.22. 
or his property and therefore he gave his consent. For example, a threaten that if he does not sign the contract his personal secret will be disclosed to public. A threaten must be a wrongful action. If that action is legally then the intimidation cannot be qualified as duress. For example, a threaten that if he does not sign the contract he will be sued in court to pay his debt. Regarding payment of debt, the usury act, 1938 has to be mentioned. It permits one of the parties to sue for the annulment of contract, in case there is an extravagant difference between the mutual obligation of the contracting parties and the injured party has thoughtlessly or in emergency agreed to the contract. ${ }^{10}$

Fraud is an overt act performed by one of the parties prior to the formation of agreement with the intention to deceive the other party and induce him into concluding a contract which he would not otherwise have concluded. A false statement by it self is not fraud, it must be accompanied by a deceitful act. For example, mere omission such as failure to inform a potential buyer of hidden defect is not a fraudulent act because is not overt, and the act must be of such a nature that the deceived party would not have entered the contract but for deception. ${ }^{11}$

A suit to avoid contract on grounds of mistake, duress or mistake can be initiated only by the injured party, and it must be brought within five years of the cassation of the duress or within five years of the discovery of the mistake or fraud. The victim may state that the consensual defect for a defense for the claim of breach of contract brought against the victim. There is no prescription on their use as a defense.

As a practical matter the Indonesian courts applies the doctrine of undue influence as well. Undue influence is a legal doctrine saying that when one of parties has dominant position to another he may abuse his dominant position and induce another to enter the contract. Kind of dominant position can be economically or psychologically. For example in NY Boesono case the debtor was retired person who desperately need money. The debtor enter the oral loan agreement with $10 \%$ interest monthly and put the pension book to secure the payment of debt since economically the creditor has economic power. In another case, Made Oka Masagung v. PT Bank Artha Graha, Notary Koesbiono Sarmanhadi SH, Sugianto Kusuma and PT Binajaya Padukreasi, case No. 3641 K/ PDT/2001, the Supreme Court held that one of requirements of valid contract is that consent must be given in free will Made Oka Mas Agung signed agreements and the Sale and Purchase Deed, transferring his real properties when he was in prison. In reliance to Bank Artha Graha's promise to release him for police custody, he was induced to transfer his real properties. The Supreme Court declared that Bank Artha Graha conduct constituted undue influence/misbruik van de omstandigheden and therefore, these sale and purchase agreements and the Sale and Purchase Deeds were not valid and annulled.

A second requirement for a valid contract is capacity. As a general rule all persons are legally capable of entering contract, except minor and the person placed under guardianship. Contract concluded by minor or person placed under guardianship can be annulled by court of law, upon application of the incapable party or his lawfull representative, provided the action is brought within five years. The obligation of the other party to the agreement is unaffected by

${ }^{10}$ R.Subekti. (1988). The Law of contracts in Indonesia; Remedies of Breach. Jakarta: CV HAJI MASAGUNG. p.4.

${ }^{11}$ Sudargo Gautama. (1995). Indonesian Business Law. Bandung;PT Citra Aditya Bakti. p.77. 
incapacity unless and until the contract is annulled. The legal issues if a minor misrepresent his age shall he be bound to the agreement since the other enters contract in reliance on his misrepresentation?

According to article 108 the Civil Code a married woman has no capacity to enter a contract, unless he was assisted by her husband. However, as a practical mater, notaries in Indonesia was drawing up contract on behalf a married woman without paying attention to article 108 the Civil Code. The assumption was that the court would not enforce article 108 the Civil Code since it was manifestly unjust and it counterpart in Holland had already been repealed. After the promulgation of Married Act Number 1 Year 1974 a married woman has capacity to enter the contract without assisted by her husband.

Corporation and association which qualify as a legal entity or juristic entities have the same capacity to contract as individual or natural person. Since corporation is an artificial person it is represented by the board of management in concluding a contract. The capacity of legal entity is related to it article of association stating the intent and purpose of its establishment. Corporation has a legal capacity to enter a contract as long as the contract made in the scope of article of association. Otherwise if a corporation carryout a contract beyond its article of association it constitutes ultra vires. ${ }^{12}$

The third requirement for valid contract is certain subject matter. By subject means the content of contract, for example to be delivered the type good must be specified (e.g.cotton) in contract it is not necessary for the contracting parties to specify the precise quantity of good when the contract is made provided that some basis is given for determining quantity in future. In general the subject of contract may be right an obligation, services goods or things, whether in existence or o come into existence so long as they are determinable. For example, it is common in Indonesia that a buyer indent a car to a car dealer. A contract to sell a car which had not belongs to a car dealer yet is law full provided that at the time of performance it is belongs to car dealer and therefore it has authority to deliver the said car to its buyer. On the other hand, a contract which is impossible of performance at the time it is performed is void. There is no requirement of reciprocity, the Civil Code specifically mention that a person may oblige himself to another without anything in return. In contrast under the doctrine of consideration in common law, a contract without consideration is not legally binding.

The fourth requirement for valid contract is that it must have lawful purpose. If the content of contract is unlawful or it is contrary to good moral or public policy, then the contract is void. For example the District Court of Central Jakarta held in Perusahaan Listrik Negara v. Payton Energy case No.517/PDT. G/1999, that the Power Purchase Agreement was void since it violate article 33 of the 1945 Constitution. PLN bought electric from Payton in US Dollar and sell it to Indonesian people in rupiah. Even thought under the Electricity Act private sector may participate in electric procurement but under President Regulation Number 37 year 1972 states that the price must be in rupiahs. In this case PLN bought electric from Payton for USD 8,56 cent/kwh whereas PLN sold to its consumer for Rp 297 or USD 2,79 cen /kwh. Even the sale contract provides

${ }^{12}$ Fred BG Tumbuan, "Pendirian Perseroan Terbatas dan Pertangungjawaban Direksi dan Dewan Komisaris serta Pihak terkait lainnya.(Makalah disampaikan pada Seminar Dengan Pendapat Publik Berkenaan Dengan Perubahan Aspek Hukum Perseroan Terbatas, Jakarta 24 September 2001), p.7. 
that the parties chose arbitration for dispute resolution but PLN brought the case based on tort law under article 1365 the Civil Code. Article 10 letter h the Law No.30 Year 1999 on Arbitration applies severability principle. Severability principle means that even thought for some reason a main contract is void however the arbitration clause is still remain valid. To avoid kind arbitration clause it is common that one of contracting parties bring the case to courts based on tort law instead of based on contract law. According to my opinion there is a loop hole in BANI Arbitration Clause: "any dispute arising out to this contract shall be settled by National Arbitration Board in accordance with BANI Arbitration Rules which is legally binding for contracting parties as the first and final decision. Whereas UNCTRAL arbitration clause says, "any dispute, controversy arising out of or relating to this contract, or the breach, termination, or invalidity thereof, shall be settled by arbitration in accordance with the UNCITRAL Arbitration Rules".

As a general rule no writing requirement to have a valid contract and contract under the Civil Code. Mutual consent of the parties is sufficient to make legally binding contract. However the Civil Code does provide exception to this general rule, for example, compromise agreement to settle disputes must be made in writing, conveyance of hyphothec must be registered and there are a few contracts which become binding only upon delivery of the subject matter of the contract, such as a deposit agreement. Under the Law No.40 Year 2007 on limited Liability Company to establish a limited liability company, a deed of incorporation must be made in notary document. If the formal requirement is not satisfied then the contract is void.

It is important to note that regarding the conveyance of title article 584 the Civil Code adopts the nemo plus iuris legal doctrine and causal system. That for valid conveyance it must be based on legal title underlying it and such conveyance must be performance by a person who has authority to convey it. It is different from the French Civil Code adopting abstract system that the conveyance of title is valid regardless the validity legal title or legality of a seller in doing so.

Under the Indonesian Civil Code, agreement it self does not constitute conveyance of title. For example article 1458 the Civil Code states that the sale contract is concluded upon mutual consent on good and price even if the good has not yet been delivered and the price has not yet been paid. Article 1459 the Civil Code explains that ownership of the said good is conveyed to the buyer only after it is delivered in accordance to article 612, 613 and 616 the Civil Code.

Under the causal system, if the conveyance of title is performed without a valid legal title or it performed by a person without authority, the said conveyance is void. However there is exception to article 584 the Civil Code. Article 1977 paragraph 1 states that one who obtains physical possession to movable good he is considered as the owner of the said good. According to Paul Scholten the purpose of this rule is to facilitate trading on movable good that it is not necessary for the buyer to investigate legality of a seller but the said conveyance must be based on legal title (legitime theory). Another legal theory namely eigendoms theory proposed by Meijer that based on article 1997 paragraph one it is not necessary for a buyer to investigate legality of seller and legality of contract as well. In conclusion article 584 the Civil Code is only apply for conveyance of immovable good. 
With regard to enactment of Basic Agrarian Law Number 5 year 1960, article 5 states that the Basic Agrarian Law makes adat for the basis of Indonesian agrarian law. Therefore adat contract law exclusively use for transaction involving land and things that affixed one with land. Under article 19 Government Regulation Number 10 Year 1960, the conveyance of land shall be made in writing with an authentic deed in front of the Land Deed Officer namely Pejabat Pembuat Akta Tanah. However the validity of conveyance of title, according to the Supreme Court verdict number 123/K/SIP/1970 is not determined by article 19 the Government Regulation but it is determined on material requirement as follows: a seller has authority to sell the said land; a buyer has a right to buy and own the said land; the said land is legally available for selling and buying and the land in question is not in disputed. In my opinion the requirement established by the Supreme Court constitutes nemo plus iuris legal doctrine and it is consistent with the negative system in land register under the Basic Agrarian Law. Article 19 Basic Agrarian Law says that certificate of title gives strong evidence of land ownership. It means that the real owner may oppose the validity of certificate of title at any time. However with regard to enactment of Government Regulation Number 24 year 1997 on Land Registration, article 32, paragraph 2 it says that after five years of the issuance, the validity of certificate of title become absolute evidence of ownership. In my opinion regarding the system of conveyance and land registration under the Basic Agrarian Law now is moving from causal and negative system to abstract and positive system. In other word it is now mixed system causal-negative and abstract positive.

Nemo plus iuris legal doctrine is also adopted in article 1168 the Civil Code states that hyphotec shall be encumbered by a person who has authority to convey it. In Juned Adiwidjaya verus PT Bank Rama Semarang Office, Hartanto Ny Ratnawati and Notary Hadi wibisono, the Supreme Court in case No.2196K/ Pdt/1992, held irrevocable power of attorney to encumber hyphotec is void since it made without consent from Juned Adiwijaya. Juned adiwijaya and Ny Ratnawati is spouse and this dispute involved marital property belong to the spouse. However in another case Bank Dagang Negara versus Ny Mara Diah and Saipul Lapia, the Supreme Court in case No.1755K/PDT/1977, dated 26 April 2001, held that hyphotec is valid even thought it was encumbered without consent of the wife namely Mara Diah. In the Supreme Court point of view the said loan agreement secured by hyphotec was given for benefit of family business and therefore Mara Diah as the wife also gain benefit. In my opinion in this case Mara Diah impliedly gave her consent to her husband to encumber the hyphotec in question.

The question of authority is also become legal issues in corporate law. Article 102 paragraph 1 Law Number 40 year 2007, says that the board of management shall obtain prior approval of the general meeting of share holder before conveying or encumbering more than 50\% corporate asset. However, according to article 102 paragraph 4 non obtainment of the general meeting share holder approval prior the said transaction performed by the board of management shall not cause the company not to be bound by the transaction provided that the other party with whom the transaction was performed in good faith. The burden of proof is thus with the company pursuant to Article 1865 the Civil Code. The above provision means that no obtained of prior general meeting shareholder has no external effect. In my opinion the policy underlying this rule is to protect the third party with good faith. 
However, in PT Oesaha Sandang v. PT Dhaseng, PT Interland and Mediarto Prawiro, case No.3264.K/Pdt/1992 dated 28 August 1996, the Supreme Court, held that PT Dhaseng and PT Interland were not liable to the debt arise out from textile sale agreement signed by Mediarto Prawiro as president director. In this case PT Oesaha sandang sold textiles to PT Dhaseng and PT Interland.In the year of 1986 PT Oesaha Sandang proposed claim to PT Dhaseng and PT Interland to pay the rest of textiles price which were not paid up by them. Finally, Mediarto Prawiro as the President director signed acknowledgment of indebtedness without prior approval from the supervisory body. In my opinion in this case the previous contract textiles sale agreement was converted to debt contract between creditor and debtor namely novation governed in article 1413 the Civil Code. The Supreme Court held that Mediarto Prawiro is personally liable to pay the debt. Critique to the Supreme Court verdict that PT Dhaseng and PT Interland had obtained benefit from the textiles sale agreement that such textile had already delivered to them. In the article of association of PT Dhaseng and PT interland there is no obligation for President Director to have prior approval from the Supervisory Bodi before entering sales contract. However when the corporations borrow money, the president Director shall obtain prior approval form the supervisory body. However in this case PT Oesaha Sandang was in good faith when made these agreements and therefore in my opinion it shall be protected..$^{13}$

Under the classical legal doctrine, a null and void contract does not create legal relation between parties and therefore, there is reason to claim for performance and damages. This rule will be fair when both contracting parties have not performed their obligations. However, if for some reason later on, the contract become null and void when one of contracting parties have performed his obligation and another have not, the first party can not legally claim for performance and damages to another party and it causes "unjust enrichment" that one get benefit from other for free.

For example in Ny. Tilaar v. J. Kunzel, Ny. Tilaar bought two pieces of land and she made a written declaration that the money to pay the price of such land came from J. Kunzel, a Germany citizen and therefore she made irrevocable power of attorney to J. Kunzel stating that Kunzel had authority to appropriate and manage the land. J Kunzel brought this case to the court asking the court to punish Ny Tilaar to convey the said land to him. However, finally the High Court of Jakarta in case dated 30 April 1984, held in favor of Ny Tilaar that the written declaration and irrevocable power of attorney is void due to violate article 1335 the Civil Code and article 21 and 36 Basic Agrarian Law. Article 21 Basic Agrarian Law mentions that in principle, right of ownership may be owned only by Indonesian nationals and article 36 Basic Agrarian Law states that in principal, right of building may be owned only by Indonesian people. Article 1335 the Civil Code says that "An agreement made without any causes or arising from a false or illegitimate cause shall be invalid".

There is an opinion that in case like this the aggrieved party should have independent course of action separately from the said void contract. ${ }^{14}$ For

\footnotetext{
${ }^{13}$ Suharnoko dan Endah Hartati. (2005). Doktrin Subrogasi, Novasi dan Cessie. Jakarta: Kencana. p.71.

${ }^{14}$ Catherine Tay swee Kian and tang See Chim. (2000). Contract Law. Singapore: Times Edition. p.94.
} 
example, suppose based on acknowledgment of indebtedness he claims for money instead of claim for property.

To solve this problem in other countries with Civil law and Common Law, there is legal doctrine namely quasi contract that when the contract is null and void, the aggrieved party may claim under quasi contract to have restitution for his performance as to prevent unjust enrichment.

\section{Structure and Content of Contract, Interpretation and Performance ${ }^{15}$}

First of all, the title of contract shall represent what the intent and purpose of parties. It will be better that the title of contract is specific and not in general such as "AGREEMENT" or "COOPERATIVE AGREMENT". Even if the title of contract is specific enough but it can be multi interpretation when we look at he content of contract, for example between CONTRACT OF WORK and LABOR CONTRACT. Basically in the contract of work the owner of project does not care how such work be performed by the contractor since the most important point is that the result of work is comply with specification and therefore there is no requirement for supervision. On the other hand labor contract required supervision from employers to employees that employers give order how the work shall be performed by employees; work and wages. As a practical matter however sometimes it is necessary for the owner of project to supervise the contractor, the legal issue is whether such supervision create employeremployee relationship? It can be argued that such supervision constitute quality control only, but in my opinion this case enters a grey area. Article $1601 \mathrm{c}$ the Civil Code mentions that," In case an agreement has the characteristic of labor agreement as well as any other kind of agreement both of the provision of the labor agreement as well as those of other agreement with similar character may apply. If however there is any contradiction between those provisions, the labor agreement shall apply".

Another example is, between FRANCHISE CONTRACT and AGENCY/ MANDATE and LABOR CONTRACT. It is common in franchise contracts that franchisors require franchisees to comply with quality specified by franchisors and therefore franchisors supervise the franchisees in term of quality control. The legal issue is whether such quality control creates agency relationship or employer and employee relationship? The rule is when the title of contract is not in accordance with the content of contract then the content of contract governs the contract. Therefore, in franchise contract there is an operative clause namely non agency and non employer-employee relationship clause that franchisor confirm there is no agency relationship between franchisor and franchisee; there is no employer and employee relationship between franchisor and franchisee. In conclusion transaction/operative clause creates legal relation between contracting parties and explains the substance of contract as well. Article 1342 the Civil Code says that, "If the wording of an agreement is clear one may not deviate from it by interpretation."

The place and date of contract is important since the date of contract usually is date when the said contract is concluded otherwise the contract it self mentions another date. It is also important if the date of payment o the date of delivery of good refers to the date of contract, for example the seller shall deliver the said good in 30 days after the contract is concluded. When the

\footnotetext{
${ }^{15}$ For discussion on Structure of contract, see also, Scott J. Burnham, Op.Cit. p.220-245.
} 
contracting parties are natural person or legal person from different jurisdiction it is important to note that formation in writing date can be different from one to another country. For example: day/month/year or month/day/year. Therefore, it will be better that the month is written in letter instead of in number. ${ }^{16}$

The identity of contracting parties must be clear since according to article 1315 juncto article 1340 the Civil Code that a contract is legally binding only for the contracting parties. If the contracting parties are legal entity it is important to mention it specifically the classification of legal entity, such as limited liability company, foundation or cooperative, and also kind of association such as partnership etc. it I also important who is natural persons representing legal entity that this person has authority to represent the said legal entity inside and out side the court, in accordance to law and article of incorporation. When clarify the identity of contracting parties it shall be consistent. For example this loan agreement is concluded between Hong Kong Shanghai Bank and Mr. Abi on 21st August 1999. In the transaction clause don't mention Hong Kong Shanghai bank as a lender. It is also important to specify the nationality of contracting parties and the address of contracting parties. For example Limited Liability Company organized and existing under the Indonesian Laws or an individual is a citizen of Republic Indonesia. Regarding the address it shall be the business domicile of contracting parties.

Recital Clause or Whereas Clause is clause explaining intent and purpose of contracting parties. It is important to clarify intent and purpose of contracting parties to solve problem when dispute arouse in interpreting transaction/ operative clause. For example in recital clause states that to secure the all debt arousing from financial leasing agreement the pledgor has agreed to pledge its shares in PT ABC (as defined below) and enter to Share Pledge Agreement with Creditor- Pledgee. When the transaction clause says that the duration of share pledged agreement is limited but the pledge has option to extend the pledge of share agreement then the legal issue is whether such extension shall be approved by the pledgor or it is extended just by notification only?

A recital clause is also important to confirm how important some term and condition. For example in premise or whereas clause it is mentioned that the buyer is doing business in making high technology component. This kind of business demand precisely specification that mere deviation will cause defected product and under standard. This recital clause explains that the contracting parties require the seller of raw material/component part, shall comply with specification precisely. Therefore, when the seller fail to comply with specification then the buyer has legitimate reason to cancel the contract instead of claim for damages only. In conclusion when transaction clause causes multi interpretation then recital/whereas clause provides solution since it explains what the intent and purpose of contracting parties. ${ }^{17}$ Article 1343 the Civil Code says that if the wording of an agreement open to several interpretations, one shall ascertain the intent of the parties involved rather than be bound by the literal meaning of the words. However when the words in recital clause are confusing and multi interpreted but the words in transaction clause is clear then the transaction clause is prevail. If the words in recital clause and the words in transaction clause both are clear but they against each other then transaction clause is prevail.

\footnotetext{
${ }^{16}$ Karla C .Shippey,J.D. Kontrak Bisnis Internasional. Jakarta:Penrbit PPM. p.37.

${ }^{17}$ Scott J.Burn. Op.Cit. p.227.
} 
After recital clause comes up definition clause. Definition clause is important to achieve clarity without repetition. For example "In this agreement the words structure shall mean an office building of no less than 20 stories". Definition shall be written in the present tense as follow; "In this agreement, the word structure means an office building of no less than 20 stories". Other examples: "Agreement means this Share and Purchase Agreement and includes the Schedules and Appendices" "Portfolio means the Sale Shares and the Related Assets". Related Asset means all dividends, interest and other money payable in respect of the Sale Shares and other rights, benefits and proceeds in respect of o drive from the Sale Shares (whether by way of redemption, bonus, preference, option, substitution, conversion)". The golden rule of drafting contract is that when you create a definition, make sure that you use it consistently and never change your language unless you wish to change your meaning. For example, an agreement states that, "the parties shall use reasonable efforts to timely perform this contract. A latter provision states that, "the seller shall use best efforts. This change of language may suggest that parties intended the meaning of best efforts to be something other than reasonable efforts perhaps requiring more heroic effort. $^{18}$

Transaction clauses or operative provisions are written to create legal relationship between contracting parties. Transaction clause defines contractual obligation. That the person do something or refrain from doing something. It is important to define who is the person and therefore it shall be written in active sentence. Compare these operative clauses: "The premise shall be kept in good repair", it is not clear whether the obligation is imposed to the tenant or to the landlord. It shall be, "The Tenant shall keep the premises in good repair or the landlord shall keep the premises in good repair". Basically an agreement can bind only the contracting parties except laws stipulated otherwise. Compare these operative provisions: "The apartment shall be occupied by no person other than the tenant, his spouse, children, and temporary guest, without he written consent of the landlord". It makes no sense to impose an obligation on the apartment. "No person other the tenant, his spouse, children and temporary guest shall occupy the apartment without the written consent of the landlord". It is clear that the actor is no person not the apartment, however it does not make sense for a contract to impose obligation to no person, the contract shall impose obligation on the parties. For example, "The Tenant shall not permit a person other than the tenant, or the spouse, child or temporary guest of the tenant, to occupy the apartment without the written consent of the landlord." In conclusion if operative clause is defined clearly it serves certainty between contracting parties. Article 1342 the Civil Code states that "If the wording of an agreement is clear one may not deviate from it by interpretation".

Transaction /operative clauses is also defines representation and warranty to solve legal issues what if the promise is not kept; what if the fact is not as represented and what remedies are contemplated. Article 1348 the Civil Code says that "All promises stipulated in an agreement shall be understood each other in the context of the agreement as a whole". Sale Agreement is basically bilateral agreement where the seller has obligation to deliver the said good and the buyer has obligation to pay the price. To make sure that the obligation of seller is condition of precedent for the obligation of buyer, the contracting parties put

${ }^{18}$ Scott J.Burnham. Ibid. p.228. 
the representation and warranty clause as follow: "Buyer obligation to perform and to complete the transaction is conditional upon the material accuracy and correctness of seller's representation and warranties. Seller delivery to buyer a certificate that seller's representations and warranties are substantially true as of the date." See also article 1478 the Civil Code, "the seller is not obliged to deliver the good if the buyer dos not pay the price and seller has not allowed him deferment of payment".

Furthermore,transaction clause/operativeclausealsoprovidesdeclaration of contracting parties. Declarations commonly include provision regarding: Force Majeure; Choice of Law, Merger /clause of integration; Assignment and Delegation; Modification; Severability and Heading.

Force Majeure clause answer the question what if performance becomes impracticable because of event of beyond the control of promisor, who bears the risk? It is important to stipulate force majeure clause, even thought if the contract is silence to answer then the contracting parties shall refer to the rule stipulated in the Civil Code. The most important and controversy provision is article 1460 the Civil Code that the risk of sale which has its object a thing certain shall be borne on the purchaser from the moment of the contract is made, in spite of the fact that the ownership remains with the seller until the moment delivery. Therefore if the said good is perished prior to delivery due to force majeure, the buyer must pay the price even thought he does not receive the said good.

As a practical matter, article 1460 has been interpreted rather narrowly by the courts so that in number of situations the risk imposed to the seller. In the first place, "a thing certain" has been held to mean only an irreplaceable item specifically pointed/designated by the buyer as which he desires to purchase it. ${ }^{19}$ For example the car which is already available in car dealer showroom. If for example the buyer enter a car sale contract with such specification but the said car has not been available yet at the car dealer show room then the seller bears the risk until the car of those specification has actually been delivered.

Secondly article 1460 has been held to apply only in situations in which the good in question have actually perished prior to delivery. If the non delivery is a result of a regulation prohibiting export of the type of goo $\mathrm{d}$ in question to the country of the buyer, article 1460 is not applied. ${ }^{20}$ For example, the Ministry of Trade issued regulation stating that export of sand and soil sand is forbidden and it is subject to criminal sanction under the Environmental Act. The Supreme Court, issued the circulate letter of 1963 No.3 stating that article 1460 of the Civil Code shall be declare void. It is interpreted that the letter only persuades judges not to apply article 1460 of the Civil Code.

The Civil Code itself in some cases, may not give certain answer regarding the assignment of risk, for example in famous case namely Jordan case, Jordan enter to hire purchase contract with the car dealer. The said car was delivered to him but he paid the price in installments. When the Japanese Army occupied Indonesia in the year of 1942, the army confiscated the car. The question is shall Jordan continually pay the price to the car dealer or not? The District Court of Surabaya, case No.263/1950 Pdt, dated 5 February 1951, held that Hire Purchase agreement is basically lease agreement and therefore there as no obligation to Jordan to continually make payment to the car dealer. This verdict refers to article 1553 the Civil Code that," If during rent period the leased good

${ }^{19}$ Sudargo Gautama. (1983). An introduction to Indonesian Law. Bandung;Alumni. p.137.

${ }^{20}$ Ibid. 
is by any chance wrecked entirely, the lease will be legally be void. If the good is destroyed only partially, the lessee has according to the circumstances of the option to request a reduction of the price or even cancellation of the lease; he may, however, in no case claim a compensation of losses." However the High Court of Surabaya dated 30 August 1956, had different point of views, that hire purchase agreement is basically sale and purchase agreement an therefore under article 1460 the Civil Code, Jordan bears the risk. Jordan had to pay the rest of car price to the car dealer. Article 1460 the Civil Code says if the good is certainly determined thing, the buyer bears the risk from the moment the selling contract is concluded although delivery has not yet been carried out and the seller is entitled to demand payment of the price thereof". Jordan brought the case to the Supreme Court but the Supreme Court refused to take his case on the ground that the dispute concerning question of fact. Critique to the Supreme Court verdict that is a question to qualify hire purchase agreement is question of law.

Declaration of Choice Law, answers the question if contracting parties have a dispute, what law shall apply? As a general rule the parties are free to specify the applicable law, subject to relevance and to the public policy of the jurisdiction asked to apply it. Choice of law can be expressly or impliedly mentioned in their agreement. The contracting parties may also make choice of forum to settle their dispute. However In the common law system there is a legal doctrine namely forum of non convenient where is the judges may refuse to take the case.

Declaration of Merger or entire agreement clause, answers the question where is our agreement found and will provision not included in the written final agreement be enforceable? For example, "This agreement is the entire understanding between the parties. The Seller is not bound by any statement, representations, promises or inducement, regardless of whether made by seller, an agent or employee, unless it is set forth in this Agreement. The buyer specifically agrees that no reliance has been placed on any representations other than the provisions contained in this agreement". Another example," This written contract is intended to be final and complete expression of our agreement and no additional term or modifications can be add or made otherwise in writing". To avoid the written contract being contradicted by oral evidence, common law lawyers are very often includes entire agreement clause like mentioned above. Given the objective approach to interpretation, it I likely that the court will only look at the writing and not the context and the negotiations to determine the intent of the parties. The courts are prevented from hearing factual witnesses that would testify that the parties did not intent what they wrote. The Parol Evidence Rule states that writing cannot be contradicted by parol evidence which is old French for oral evidence. The common law takes an objective approach to what the contract is. It does not ask what each person intended and whether what they actually intended is the same (meeting of minds). ${ }^{21}$ Common la court ask what a neutral third party standing by and hearing the exchange of offer and acceptance or reading the writing contract would think the contract is. This is an objective approach in the sense that it does not look at the actual intent of the parties (the subject) but seeks the meaning of the words as they

${ }^{21}$ Gary F.Bell. (2005). “Comparative Contract Law:with a few insight on evidence”, presented at Faculty of Law university of Indonesia, 19 May 2005. p.12-14. 
would understood by an objective third party. ${ }^{22}$ But how about if in the fact this agreement is not complete that the agreement is silence to certain legal issues? In my understanding in this case, it is legal to invoke oral evidence to solve the problem.

The civil law tends to take subjective approach to the formation and interpretation of contracts. The contract is hat the parties have actually intended as much as possible and the court will look at what they actually intended rather than the word actually used. For example, article 1343 the Civil Code mentions that 'If the wording of an agreement is open to several interpretations, one shall ascertain the intent of the parties involved rather than be bound by the literal meaning of the words". ${ }^{23}$ It will certainly allow evidence of prior negotiations and evidence of expressed intent other than the writing to interpret the contract. However in my opinion, civillaw court does not prevent to take objective approach as well. For example, The Share Pledge Agreement states that the duration of the agreement is limited before all debt has paid but the creditor-pledgee has option to extend the said Pledge of Share Agreement. The legal issues issue is whether to extend the agreement the creditor -pledgee has to obtain approval from the debtor-pledgor or he just give notification to debtor-pledgor?

Taking subjective approach the court will look at the intent of parties during General Meeting of Share Holder prior they enter share pledge agreement. Taking objective approach the court will ask expert witness as the neutral third party to seek the meaning of the words as they would be understood by an objective third parties. The third parties may interpret the contract in accordance to article 1345 the Civil Code "if wording is open to double interpretations, it should be interpreted in accordance to the nature and character of the word in question." It may lead to the conclusion that the nature and character of pledge agreement is accessory or depended on the debt contract.

Declaration of assignment and delegation answers the question "can the right and obligation under this agreement be assigned or delegated". According to article 1315 juncto article 1340 the Civil Code, only contracting parties may be bound or benefited under the contract. In other word as a general rule contract can not impose liability on a third person, and third person cannot acquire any right under the contract to which he not a party. However the parties may assign their right and duty or delegate their rights and duties under the contract to third party the contract. Assignment or delegation can be imposed by agreement or it can be imposed by law. Assignment causes the previous legal relation be discharged whereas in delegation, delegating party is still liable if delegated party does not perform it.

Under article 1317 namely promise for the benefit of third party. This is done merely by stipulating that the agreement should benefitted for a designated third person and then having the third party beneficiary ratify the stipulation before it revoked. For example A landlord promise to B tenant to lease his premises subject to stipulation that $\mathrm{C}$ receive the money. $\mathrm{C}$ must accept the $\mathrm{A}$ offer in order to acquire enforceable right. If $\mathrm{B}$ tenant pay to $\mathrm{C}$ then the obligation of B to A is discharged.

Article 1316 states that "However it is allowed for the parties to give warranty that third person accept and perform obligation but if this third person refuse to accept the said obligation then the warrantor is liable". In my opinion

\footnotetext{
${ }^{22}$ Ibid.

${ }^{23}$ Ibid. p. 12.
} 
article 1316 constitute delegation. Article 1316 the Civil Code refers to cheques regulated to in he Commercial Code, it is different from article 1820 Civil Code on Surety Agreement.

Article 1318 the Civil Code constitute assignment imposed by law that," All right and duties arising out of a given contract pass to the heirs in the even of death and pass to third party who acquire the right from contracting parties unless the contract clearly provides to the contrary." For example A, the car dealer sell the car to B with after sales services within one year. Before one year B sell the car to $C$ and by operation of law promise for after sale service is enforceable for $\mathrm{C}$ otherwise A confirms to B that after sales service is only bound to $\mathrm{B}$.

Contracting parties may enter sale agreement to assign his lien/ claim form one to another. For example based on loan agreement A creditor has a claim/lien to B the debtor and A assign his claim to C. according to Article 613 paragraph 1 and 2 that delivery of personal lien shall be performed by means of an authentic deed or private deed by which the right of such claim is transfer to other, namely cessie. Such transfer has no consequences to the debtor unless he has been notified or that he has accepted or acknowledged the transfer in writing. The party who transfer the said lien is namely cedent, the party who acquired the right is namely cessionaries and the debtor is namely cessus. Artcle 1492 the Civil Code states that "although the sale did not include a warranty clause, the seller is obliged to warranty the buyer against any eviction which he might suffer regarding the entire good sold or part thereof, or regarding any encumber that may be claimed on the good and which had not been mentioned when the sale good took place." Under this article seller/cedent is not obligated to give warranty that the debtor will pay the debt to buyer/cessionaries otherwise it is provided in their agreement.

Assignment of right and duty may take place in form of novation stipulated in article 1413 the civil code as follows: "(1) when a debtor in the interest of his creditor accepts a new obligation, substituting the old one, which is abolished by that; (2) when a new debtor is accepted to substitute the form debtor who is release by the creditor of his obligation;(3) when as consequence of a new contract a new creditor is accepted to substitute the former one with regard to whom the debtor is released from his obligation."

Declaration of modification answer the legal issue if the parties change the agreement, is the original agreement or the modification agreement effective? Article 1338 the Civil Code says that "All agreement concluded legally is legally binding as the law for contracting parties". "The agreement can not be revoked except by mutual consent of he parties or for sufficient reason declared by law". The agreement shall be performed with good faith".

Under the civil law system modification agreement is prevail as long as it is concluded by mutual consent. For example, on October $1 \mathrm{~A}$ shall buy and B shall sell to A his Toyota Alphard for 800 millions rupiah. On October 5 A shall buy and B shall sell to A his Toyota Alphard for 900 millions rupiah. Under civil law system the second agreement entails novation or at least modification of prior obligation and therefore A shall pay for 9000 millions rupiah.

However under common law some modifications of the contract might be not enforceable even if both parties agree. In second agreement A promise to pay more but B has promised nothing new in exchange that he sell the same Toyota Alphard. Under the doctrine of consideration promise without consideration is 
not enforceable. In this case B shall give fresh consideration to $\mathrm{A}$ in order to discharge first agreement. For example, providing insurance. This may cause some unfairness if one relay on the other promise but it is not enforceable. The solution under common law is by applying the doctrine of promissory estoppels, but the solution offers limited protection to the party relied on the promise. In the United States there has been reform under article 2 of the Uniform Commercial Code, that an agreement modifying a contract within this article needs no consideration to be binding. ${ }^{24}$

Example of declaration of modification / amendment clause: "the amendment shall be made in written document signed by both parties".

Declaration of Severability, answer the question if the court refuse to enforce part of agreement, will it give effect to the remainder? For example this severability clause confirms that if a part of agreement for some reason become invalid later on, the rest provisions remain valid. "In the event that any or more of the provisions of this agreement shall be held to be invalid, illegal or unenforceable in any respect, such invalidity, illegality or enforceability shall not affect of the other provision hereof, which shall nevertheless remain in force and effective"

The closing of agreement should demonstrate that the parties assent to it by affixing their signature. Article 1870 the civil code mentions that an authentic deed furnishes the parties and their heirs or person who acquired right from the parties, a perfect evidence of its content". Article 1875 the Civil Code mentions that," A private document which is recognized by person to whom this document presented against him furnishes to persons who sign the document and their heirs and person who acquire the right from them, the same perfect evidence as an authentic deed and the provision in article 1871 Civil Code us applicable for them".

\section{Non Performance and Remedies}

There are three manifestations of breach of contract a) total failure to perform the agreement b) failure to perform the agreement in time and c) failure to perform the agreement properly.

If the agreement provide when the time of performance specifically, the party who fail to perform it in time would be in state of breach of contract. A problem arises, if no time period is specified in the agreement, the party who fails to carry out the agreement must be notified in writing before any court action can be taken against him. Notification may take in form of official summon by a court clerk appointed by a judge delivering it. The advantage of using this procedure is that the statement of the court's clerk qualifies as full means of proof that a summons has taken a place. However the aggrieved party may summon the breaching party in private.

Official or private summon is not necessary if the party has declared that he will not fulfill his obligation. The duty to pay damage begins form the moment the party fails to fulfill his obligation however duty to perform an obligation for paying a sum of money begins from the dated that the law suit is filled.

Remedies can be divided into specific performance and damages. In civil law the aggrieved party is usually entitled to specific performance. The goal of this law is to encourage moral honorable behavior. The goal of remedy is not to

\footnotetext{
${ }^{24}$ See also, Gary F.Bell. Ibid. p.5.
} 
compensate the aggrieved party but to hold people for their word unless the actual performance is impracticable or the aggrieved party is ready to have compensation.

Under article 1234 the Civil Code there are three kinds of obligation: obligation to deliver something; obligation to do something and obligation to not to do something/forbearance. Article 1239 to article 1242 the Civil Code mentions, if one of parties failure to fulfill obligation to do something or not to do something, the court may award the aggrieved party, specific performance and if the defendant does not obey the court order, the plaintiff may ask for mandate from the court to perform the obligation by him self or to abolish everything have been done by the defendant. In commercial practice, obligation not to do something/forbearance takes in form of negative covenant. For example, the debtor is not allowed to convey or to encumber his property without prior consent from the creditor and if he violates the agreement it constitutes default. Another example is negative covenant not to compete, that one year after the franchise agreement extinct, the franchisee is not allow doing the same thing business.

Whereas under the Civil Code, there is no such provision in case one of party failure to deliver something. Under the Civil Code is impracticable to ask specific performance to deliver immovable good since acte van transport can not be replaced by court order. Acte van transport shall be perform by both the seller and the buyer bilaterally.

However in the Netherland in my understanding, the High Court of Den Haag and Hoge Raad in case Verploegh v. van der Meer and van Doorn held that the court order may replace the declaration to transfer of title/acte van transport by the seller. ${ }^{25}$

Even thought under the Basic Agrarian Law and Government Regulation on Land Registration, the Sale and Purchase Deed made before the Land Deed Officer can not be replaced by court order. In case No.350K/Sip/1968 the Supreme Court held that in case the seller can not convey the house to the first buyer since it was delivered to the second buyer, therefore the first buyer may only ask the court to cancel the agreement and to award damages. In practice, the seller made irrevocable power of attorney to the buyer authorizing the buyer to sell the said piece of land.

In case one party failure to perform his obligation to deliver movable property and such movable property has delivered to third party, the plaintiff will face provision of article 1977 paragraph 1 the Civil Code that one who obtain physical possession of movable good is considered as the owner.

In addition to performance or in lieu thereof, the aggrieved party may sue fro damages. Damages consist of money compensation for any or all of three types of injuring resulting from breach of contract, there are "expenditures" (kosten), losses (schaden) an interest/lost profit (interessen). Expenditures include all expenses and cost actually incurred by the aggrieved party in reliance of the contract. By loss means injury to the said good which are object of contract and injury to others property resulting from the default. Interest refers not to interest as such in loan agreement but it refers to lost profit.

The Civil Code imposes certain limitation on the amount of damages as follows; a) damages are limited to injuries which were foreseeable at the time of

${ }^{25}$ Van der Burght. Op.Cit. p.18-20. 
formation of contract. According to case law, the scope of the loss as well as the possibility of injury must have been foreseeable (article 1247 the Civil Code); b)damages are limited to those injuries which are immediate and direct result of the breach(article 1248 the Civil Code); c)in the case where performance to be in the from a payment of money, the Civil Code permits the court to award interest and is measured not from the date of the breach but form the date on which the petition for damages if filed with the district court (article 1250 the Civil Code) However the interest which can be claimed is limited to $6 \%$ per year(state gazette 1848 Number 22).

In the common law, specific performance is not a right but an equitable remedy (i.e. discretionary), which are rarely granted that the judge normally award. This has led some American legal scholars to the concept of efficient breach. It is totally acceptable to breach of contract and pay compensation and you should do if you can efficiently make more money through entering another contract. For example in Long Beach Drug, Co v. United Drug Co, plaintiff was appointed as the sole distributor to sell the defendant product in Long Beach, California. This contract was concluded in 1909 and Long Breach Drug was small business with limited capital. In the year 0f 1930 the population of Long Beach had substantially grow and the chain store as the mode of distribution was introduced. By having chain stores, a company may buy much more product from manufactured in cheaper price and sell it in cheaper price also to their consumers. However, Long Beach drug was still remains as small business and it could not respond to market change where consumer demands substantially increase. The law of supply and demand says that when supply is less than demand then the price increases.

In the year of 1936, United Drug signed a contract with Owl Drug Co and terminated its contract with Long Beach Drug Co. Even though, Long Beach Drug asked to United Drug to perform their contract concluded in 1909 but the court held that termination/breach of contract was more appropriate and awarded damages to Long Beach Drug Co. ${ }^{26}$

However, according to article 1247 and 1248 the Civil Code damages are limited to those injuries which were foreseeable at the time of the formation of contract and they are limited to those injuries which are direct result of breach. In my opinion if the loss is difficult to ascertain, the court shall enforce liquidated damages clause. For example, the principal and the contractor agrees that in case the contractor fails to finish the work in specified period of time, liquidated damages will be $0,1 \%$ monthly and for maximum 0,9\%. It means after 9 month the principal may take over the project.

\section{Sale Contract and Consumer Protection}

The Civil Code defines a contract of sale and purchase contract is a contract in which the seller bind him self to transfer his ownership of good to the buyer and the buyer bids himself to pay the seller and agreed price. The civil code distinguishes between the moments of sale at the moment of transfer of ownership. The sale contract is valid and legally binding upon mutual consent of the seller and buyer in term of the said good and the price. The transfer of ownership occurs at some point after the contact is concluded. The transfer of ownership shall be performed in accordance to article 1459 the Civil Code.

${ }^{26}$ Suharnoko. (2009). Hukum Perjanjian:Teori dan Analisa Kasus. Jakarta Kencana. p.93-94. 
The Civil Code provides two warranties by the seller to the buyer: a) the seller warrants title to the goods and his right to sell them. If after delivery the buyer's right of ownership is later challenged by a third party, the buyer can compel the seller to defend b)The seller warrants the good being sold against hidden defect, including defects not known to the seller at the time of sale.

However the contracting parties may release or waive their duty imposed by the code such as the warranty against hidden defect. Therefore if the products are defect due to negligently manufactured, the seller may escape for liability. On the other hand the warranty of title can never entirely be avoided. Article 1494 the Civil Code states that "Although it may be agreed that the seller is not required to give warranty, he will nevertheless, be responsible for anything resulting from an act committed by him self. All agreement contradictory hereto will be void".

The Law No.8 Year 1999 on Consumer Protection gives more protection to the buyer as the end user. It is legal for business people or entity to enter standard contract with consumers and stipulate standard clauses in consumer contract. However article 18 of the Consumer Protection Law mentions that, it is forbidden to stipulate standard clause as follows: a)declaring assignment of liability from entrepreneur to consumers b)declaring that entrepreneur has the right to refuse return of good from consumer c)declaring entrepreneur has the right to refuse return of payment from consumers d)declaring consumer give mandate to entrepreneur to unilaterally takes action related to the good bought by consumer in cash or in installment e)arranging burden of proof on the loss of god or service bought by consumer f)giving the right to entrepreneur to reduce consumer property related to the sale contract g) declaring the submission of consumer to new, addition amendment provision made by entrepreneur h) declaring that consumer give mandate to entrepreneur to encumber mortgage, pledge or other security on property bought by consumer. In case the entrepreneur stipulates the standard clauses above, such standard clauses are declared null and void. Moreover article 24 the Consumer Law says that entrepreneur who sell good or service through another entrepreneur will be liable to consumer claim for damages as long as there is no substantial change on the said good. Therefore, if a principal sell build up cars through its agency, distributor and dealer, it will be liable for hidden defect and consumer claim for damages.

The Civil Code does not provide anything with regard to hire purchase agreement, but such agreement has developed in practice. Hire purchase enables buyer to enjoy the good immediately in spit of the fact that payment and transfer of good are not completed yet. In this kind of contract, payment is made in installment, even thought the goods are immediately delivered, the property right of the goods remain in the hand of seller until the price of goods is totally paid. Buyer can not resell or encumber the good, since he does not yet own them. Should buyer fail to comply with this prohibition, he can be punished with embezzlement.

The dispute arise when the seller unilaterally withdraw/pull out the good from the buyer possession without court order. Article 1266 paragraph one the Civil Code, states that, "The condition of dissolution of the agreement is always implied as to occur in mutual agreements, in the event of one parties does not comply with his obligation". Paragraph 2 , in such event, the agreement is not 
dissolved according to the law but the dissolution shall be requested through the court". In practice the parties declare in their agreement that they release or waive paragraph 2 article 1266 the Civil Code, but when one o party files the case to the court, usually the court takes the case.

In the 1980's the courts usually held in favor of the buyer when the seller unilaterally pull out the good from the buyer. The reason are, firstly the purpose of hire purchase contract is finally to transfer the property right from seller to buyer and the most important thing it is necessary to protect the buyers since they are lack of bargain power in facing the sellers. For example in $N y$. Lie Tjiu Hoa and Achmad Kartawijaya alias A Liong v. Linda bin H. Marsan, the Supreme Court in case No.935/Pdt/1985 dated 30 September 1986, held that it was not proper conduct to abolish the right of buyer on the good, just due to her delay in paying last installment without calculating amount of money that she has paid in previous installments. The seller may only claim for payment and property right reminded in the buyer. In another case Sie Gie Tiong v Agus Setiawan, the Supreme Court in case No.3272K/Pdt/1988 dated 30may 1990, held that ownership of good had passed to the buyer even thought the buyer had paid only two installments. Similarly in Arifin Samoga v. La Ode Abdul Latief, the Supreme Court in case N0.1241K/Pdt/1986 dated 30 March 1986, punished the buyer to pay the rest of car price but the property right had been conveyed to the buyer. ${ }^{27}$

In practice, there is another business to consumer contract. Sellers sell consumer goods with credit facilities providing by financial institutions Financial Institutions enter loan agreements with consumers and pay the price of the sold goods completely. The goods are encumbered by security namely fiduciary transfer of ownership. Under article 30 Law No.42 Year 1999 on Fiducia, the debtor is obligated to deliver encumbered property for the purpose of execution.

\section{Conclusion}

a. The development of contract law in Indonesia has beeen influenced by enactment of new laws, court verdicts and legal practices. It has been influenced by civil law and common law systems applied in other countries.

b. The enacment of Consumer Protection Act strengtens the Position of consumers against professional seller, however the coutrs have not recognized pre contractual liability during preliminary negotiation. Whereas in other civil law countries the court aplied the principle of good faith before contract is concluded and in common law country courts applied the doctrine of promissory estopppel.

c. In accordance with development of contract law in other countries, the Indonesian courts applied the doctrine of undue influence and acceptance by conduct and in some cases protected the the third with good faith after contract concluded. It should have protected third party dealing with unauthorized board of management of corporation. The enacment of Basic Agrarian Law and its Implementation Laws, especialy Government Regulation No. 24 year 1977 law imporoved the protection for buyer with good faith as to shift the

\footnotetext{
${ }^{27}$ Suharnoko. Ibid. p.73-74
} 
causal system and negative registration system to mixed system with abstract and positive registration system. However the Indonesian courts have not applied the doctrine of unjustified enrichment when contract is void but one party has performed his obligation for benefit of another party.

d. As practical matter Indonesian lawyer put integration clause in contract governed by Indonesian law eventhough such clause influenced by common law sytem. Whereas regarding this issue, Internasional Convention on Sale of Good adopts civil law system.

\section{Bibliography}

\section{Books}

Beatson, Jack, and Daniel Friedman(ed). (1999). Good Faith and Faults in Contract Law. Oxford: Clarendon Press

Bell, Gary F. "Comparative Contract Law (with a few insight on evidence)". Presented at Fakultas Hukum Universitas Indonesia, 19 May 2005.

Burnham, Scott J. (1993). Drafting Contract. Charlottesvile, Virginia: The Michie Company

Der Burght, van. (1999). Buku tentangPerikatan dalam Teori dan Yurisprudensi. terj. F. Tengker. Bandung: Mandar Maju

Gautama Sudargo and Robert N.Hornick. (1983). An Itroduction To Indonesian Law: Unity in Diversity. Bandung Alumni

Gautama, Sudargo. (1995). Indonesian Business Law. Bandung: PT Citra Aditya Bakti

Gust,A.G.(ed). (1975). Anson's Law of Contract. Clarendon Press

Harris, Donald and Denis Tallon (ed). (1989). Contract Law Today: Anglo French Comparison. Oxford: Clarendon Press

Harsono, Budi. (2004). Hukum Agraria Indonesia: Himpunan Peraturan Hukum Tanah. Jakarta: Djambatan

Himawan, Charles and Mochtar Kusumaatmadja. (1973). Busines Law: Contract and Business Association. Bandung: Fakultas Hukum Universitas Padjadjaran

Macaulay, Steward, Jhon Kidwell, William Whitford (et all). (1995). Contract Law in Action. Virginia: The Michie Company

Shippey, Karla C. (2004). Kontrak Bisnis Internasional. Jakarta: PPM

Subekti. (2004). Hukum Perjanjian. Jakarta; Intermasa (1989). The Law Of Contracts In Indonesia: Remedies of Breach. Jakarta: CV. Haji Mas Agung

Suharnoko. (2009). Hukum Perjanjian: teori dan Analisa Kasus. Jakarta: Kencana Prenada Media Group

Suharnoko and Endah Hartati. (2005). Doktrin Subrogasi, Novasi dan Cessie. Jakarta:Kencana

Rahmanata and Anjar Pachta. (2008). Civil Code For Indonesia.Jakarta; lembaga Penerbit FEUI 
Penerbit FEUI

(2009). Commercial Code of Indonesia. Jakarta; Lembaga

Tay Swee Kian, Catherine and Tang See Chim. (2000). Contract Law. Selangor: Times Edition

\section{Regulations}

Subekti, R and R Tjtrosudibio. (1992). Kitab Undang-Undang Hukum Perdata. Jakarta; Pradnya Paramita

\section{Other sources}

Tumbuan. Fred BG. "Pendirian Perseroan Terbatas dan Pertanggungjawaban Direksi dan Dewan Komisaris serta Pihak Terkait lainnya". presented at Hotel Borobudur, Jakarta, 24 September 2001. 